\title{
Coexistence or Conflict? The Problem of Dual Belief in Polish Folklore
}

\author{
Anna Brzozowska-Krajka \\ M. Curie-Skłodowska University, Lublin
}

In her work on the evolution of Slavic religion and mythology and in drawing up a stratigraphy, Marija Gimbutas was able to show that it was arranged on the following three levels: "1) Old European, rooted in a local Neolithic culture; 2) Indo-European, derived from the pastoral, patriarchal culture of the Eurasian steppes; and 3) Christian, in which pagan prototypes fused with Christian figures, producing a 'double faith.' (Christianity was introduced into Moravia in 863, Bulgaria in 885, Poland in 966, and Russia in 988)" [Gimbutas 1987: 354]. Thus the category of dual belief constitutes the third and final stage in the formation of Slavic religion, and as such is one of the invariant features of a pan-Slavic folk world view. We may find the effects of the confrontation between these two religious systems in various forms and genres of Polish folklore, especially magical folklore (such as charms/spells/incantations, private prayers of a magico-religious kind or complex magic acts). Magical folklore is undoubtedly the deepest layer and the oldest factor in shaping a way of life, one human being's relationship with another, with his or her community and with nature [Hernas 1976: 7]. In the broadest sense dual belief mean the intertwining, mutual influence, cooperation, and sometimes the combination (syncretism) of two different cultural models: paganism (pre-Christianity) and Christianity [see Tolstaia 1995: 38; cf. also Levin 1991: 31-52]. In contrast to East Slavic Christianity, which was subject to Byzantine influence, the nature of dual belief as it applies specifically to Poland is determined by Western Christianity (Roman Catholicism) and the Catholic Church's long struggle with pagan beliefs and practices. Permanent traces may be found in the high degree of Christianization characteristic of Polish folklore and in its shift from a magic-based world view, specific to the period before the coming of Christianity, to a magico-religious world view, relics of which persist even today. Dual belief is thus "a double game" - a double consciousness which may be detected in most magical practices, for example those of ritual folklore, such as that relating to funerals or weddings. Joanna Tokarska-Bakir considers the nature of this duality in a hermeneutic reading of Polish ethnographic sources from the perspective of religious folkways 
[Tokarska-Bakir 2000]. Duality, she suggests, is "changing one's loyalty" to a god or gods for a loyalty subordinated to what is more actual. It is the sacrum [Eliade 1997: $5 \mathrm{ff}$ ], the sacred, that is the domain of what is real. However, the reality of the sacrum is also a matter of degree; the old gods do not cease to be real with the coming of a new religion, whose holy sites replicate an already existing sacred geography. The old sacrum is transformed into its countersign, but at the same time it continues to conceal power in itself, surviving as a hidden force within that countersign [Freedberg 1989, passim, cited in Tokarska-Bakir 2000: 83-84].

I would like to portray this relationship between the Slavic (that is, pre-Christian) and the Christian sacrum from four perspectives: the historical, generic, structural-symbolic and functional. Obviously this is just a preliminary discussion, suggesting the direction that future research into the problem of whether dual belief is a question of coexistence or conflict might take. This topic is still terra incognita in Polish folklore studies. It should be emphasized that Polish folklorists, in contrast to Russian, Ukrainian, Belarusian, Bulgarian and others, face a difficult task in researching the magical aspects of folklore because sources are so scanty. There are various reasons for this situation, in particular the religious intolerance of folklore collectors in the nineteenth century and beyond, for whom the basis for recording local materials was their degree of proximity to the recognized religious canon or moral canon (the latter concerns collections of obscene material). Noncanonical prayers, charms, as well as obscene texts (all texts that "scandalized the people and the holy Catholic faith") were regarded as "heresies spread by the Calvinists," since those who disagreed with official Catholic dogma and practices, even in trifles, were generally known as "Calvinists" or "Lutherans." By contrast, the actual peasants were very tolerant in this respect, and would declare: "let everyone pray as he wishes, the Lord God will understand" [Kotula 1976: 464]. In making this declaration they were in effect demanding the complete freedom to decide what went into their ritual dialogues with God (transcendence) and what form these ritual dialogues should take.

The magical nature of such texts, belonging to the category of socalled secret texts and termed kryjaki by Czernik [Czernik 1971: 72], was another reason for the meager amount of data in Polish folklore. Disclosing them meant the loss of their magic power. Jan Witowt, who studied these problems, noted that "the peasants keep their conjuring strictly secret, maintaining that 'they would lose all their medicinal 
power through idle chatter and lack of belief' in their efficacy" [Witowt 1905: 558]. As late as 1967 in the region of Rzeszów (south-eastern Poland) there was an incident in which an elderly informant was asked about the transmission of non-canonical prayers, specifically the socalled Mikołajki (addressed to St. Nicholas), and categorically refused, convinced that he owed his health and strength to a private prayer he had said since childhood. If revealed during his lifetime it would lose its power, and his death would surely follow. As a guarantee of long life, it could only be passed on when he was on his deathbed, and then only to his family [Kotula 1976: 208-09]. Other observations about the texts of spells, which could not be passed on or revealed in any way, are along the same lines. There were sanctions connected to the ban. If the ban was violated, the verbal spell not only became invalid, but was transformed into a harmful force, and both disclosure and hearing it could have negative consequences [Czernik 1971: 51]. Thus it was not only observers who were conscious of the inherent "otherness" of these texts, but peasants too were aware of their non-canonical nature, and knew that the Catholic Church condemned them as sinful, even though they themselves might still go on using them.

For Christian philosophy offered a qualitatively different concept of the world, God and people, another way of making mutual contacts and connections, as well as the fact that Christianity differed from the preChristian image of the world from the point of view of the theories of cognition (gnoseology) and of values (axiology) [Novikova 1993: 291]. In contrast, however, to Eastern Orthodoxy, which while reaching the faithful, did not control them to the same extent, the paternalistic authority of the Roman Church rested upon the supervision of the thoughts of the faithful, directing their steps, and giving them detailed instructions about every moral and intellectual issue in life [Zernov 1967: 201]. This judicial authority was vested in the Roman Catholic clergy.

The oldest Polish sources pointing to a conflict between these two systems are to be found in penitential literature, the so-called books of penance. One example of this type of literature is the Latin codex Summa de confessionis discretione from Silesia, a mid-thirteenth century confessional text which is an ethnographic document written in Latin (translated into Polish and published by Karwot in 1955 as Katalog magii Rudolfa (Rudolf's catalogue of magic). Sections eight, nine and ten in Part Two of this catalog give quite extensive lists of various customs, beliefs and magical folk practices, such as methods of bringing happiness, good health, and love, while presenting them as sins against 
faith in God. In so doing, what was an instructional guide to good confessions turns into a utilitarian work, which aims to combat what the Church saw as paganism. In the opinion of the medieval historian Aaron Gurevich, these beliefs, inherited from the earliest times, on the one hand, and the Christian religion on the other, which "simultaneously had a permanent effect on each other and were in a state of antagonism, constituted two synchronic aspects of medieval social awareness, creating a specific construction which may be called folk Christianity" [Guriewicz 1987: 132]. Traditional consciousness could be deprived neither of the old gods (albeit that to all appearances they could be eliminated from reality) nor of a whole complex of practices designed to influence the world through the medium of magic. This consciousness remained unchanged or virtually unchanged over the course of many centuries. Over the centuries the clergy found it hard to cope with the vast range of superstitions and customs, and it is no coincidence that the same questions about the pagan practices of penitents were constantly being passed from one textbook of good confessions to another. We may deduce this from an example, written in 1776, found by Jan Stecki in a private library in the Lublin region. Parts were published in Wisła in 1901. It is entitled Zbiór generalny wszystkich grzechów z przykazań Boskich kościelnych z Siedmiu głównych grzechów Śmiertelnych tudziesz podług stanu y kondycyi każdego Człowieka do porachunku y roztrzaśnienia Summnienia idac spowiadać sie podany 1776 Roku (General Catalogue of All Sins from the Divine Church Commandments from the Seven Deadly Sins; likewise according to the condition and status of every man regarding the self-examination and meditation prior to going to confession, issued in 1776). The Catalogue of Sins notes that:

Ieżeliś się leczył albo kogo przez gusła z przydatkiem słów Zabobonnych Uroki odczyniając rosty (pewnie krosty) zażegnywając modlitewki zabobonne odmawiając albo się obmywając wodę na głowę lejąc $z$ modlitewkami wymyślnemi suchoty odczyniając ....

(If you treated or healed yourself or anyone else by means of witchcraft, with the addition of words of superstition, breaking evil Enchantments, conjuring pimples away, reciting superstitious non-canonical prayers, or washing yourself by pouring water over your head, or banishing tuberculosis with secret prayers ...

And:

Ieżeli Modlitewek Zabonbonnych nieumiesz y iezliś ie mawiał y Innych nauczał; Ieżeliś niezazywał modlitewek które w skutki iakie Obiecują mowiąc ie pewnych Dni lub Czasow a zwłaszcza wrzeczach nieprzystoynych.

(If you did not know superstitious private Prayers and if you neither repeated them nor taught others; If you did not recite the private prayers, which in 
essence promise results by being said on certain Days or Times, especially where indecent matters are concerned.) [Zbiór generalny 1901, 15: 653-54]

As Karwot remarked in his comments on the confessional text by Brother Rudolf cited above, you may "look for pagan customs in areas of everyday life wherever there is sin" [1955: 189].

Much of the material assembled by nineteenth-century collectors also reveals a clear discrepancy between folk religion and the established Catholic religion. For example, when Father Władysław Siarkowski was recording ethnographic and folklore materials from the Kielce area in central Poland, he wrote that "the peasants are distinguished by their strong religious feeling, but this feeling (with some exceptions) is based on external signs. Their faith stems not from 'the pure source of the Christian spirit,' but from surface forms; hence the many superstitions and prejudices among the people" [Siarkowski 1880: 111]. Józef Kibort, a collector from the Wilno area (formerly in north-eastern Poland, now Vilnius in Lithuania), maintains a similar tone in his comments. He defines folk religion as a "mixture of idolatrous remnants with an outward veneer of Christianity, mainly characterized by different sorts of non-canonical prayers, prejudices, superstitions and witchcraft" [Kibort 1897: 324]. The suggestion contained in these observations points directly to the main forms of survival of pre-Christian beliefs and practices, those magic folklore genres that are of particular interest to us: what are called private, non-canonical prayers said along with morning and evening canonical prayers and complex magic acts (that is, magic words combined with ritual actions and objects) within a framework of so-called white magic (magic rituals causing good) and black magic (magic rituals causing evil).

The active coexistence of two world models (two cultures, preChristian and Christian) may be spotted both in the structure of ideas and symbols and in the functions performed by genres of magical folklore. Magical texts preserved in collections from the nineteenth century on are modeled by the Polish variant of Slavic folk mythology which is based on the principle of cosmic order, typical of a dualistic folk world view. In private prayers said along with daily prayers, this dualism is determined by the positive sacrum - God, and the negative - the Devil, as the two antithetical demiurges found in the Slavic cosmogonic myth. This dualism does not therefore clash with Church teaching, especially as the former accepts the ethical valorization of God as the embodiment of good, and the Devil of evil. Let us recall that, according to magical thinking, various supernatural beings were not identified as unequivocally evil; rather they were ambivalent figures, whose positive 
powers could be tapped through regular contact between the "living" (human beings) and the "non-living" (deities, non-humans) in a cosmic dialogue. The essence of this contact was determined by etiquette, that is the use of numerous spells and contact formulae understood as ritualized folkways appropriate in particular circumstances. This was especially relevant in the etiquette surrounding situations of change. Thus, when change was in the offing, or when some significant change needed to be made, that change could be made effective by using the magic that could ensure a good beginning to the event. Magic would be employed to establish the right time for change to begin, according to the rule that, if you determine the beginning, you can determine the end [BrzozowskaKrajka 1998: 73-114]. The activities of the Catholic Church over many centuries did a great deal to "purify" this dialogue, offering believers canonical prayers for every occasion,(1) addressed exclusively to the Christian God and the whole Christian pantheon.

The principles according to which this pantheon functioned in the folk consciousness are exemplified by those texts of magical folklore, that is to say, charms and complex magic acts that have been preserved. They are not contemplative in nature, for folk Catholicism was devoid of the mystic, philosophical element of religion, but they do represent a source of power, understood from a utilitarian point of view, as well as a way to reinforce magical acts designed to achieve a particular result. Anthroponyms of Christian origin - the figures of God, the Mother of God, and the saints - appear in such texts of magical folklore "without their haloes." Their "authority" is understood as an instrument which might assist people to obtain some specific concrete benefit, such as recovery from illness. A closing formula that often appears in complex magic acts runs as follows [Kotula 1976: 286]:

Nie moją mocą - Boską mocą!

Pana Jezusa,

Not by my strength, but the Lord's!

Wszystkich Świętych,

Aniołów,

And that of Jesus Christ,

And of all the Saints,

Apostołów dopomocą!

And the Angels,

With the assistance of the Apostles!

Svetlana Tolstaia defines this as a distance formula (involving the recognition of God's authority), specific to sacred texts [Tolstaia 2001: 22]. Sacred objects, such as the gospels, especially the cross, which fulfils an apotropaic function protecting humans from harmful forces, appear in the structure of private prayers as symbols of power. The same apotropaic function was often ascribed to angels, that is, the heavenly host [Brzozowska-Krajka 2004: 419-26]. The precedents of sacred history, key elements in the Christian myth, served, too, as a guarantee 
that a given complex magic act would be effective, such as in the complex magic act designed to conjure away the illness known as the "rose" (erysipelas). In this the motif of Christ's tomb appears at the beginning, implying a paradigmatic resurrection situation involving rebirth for the patient [Biegeleisen 1929: 136]:

Pan Bóg leży w grobie,

Ma dziewięć róż w sobie.

Od dziewiątej do ósmej, od ósmej do

siódmej,

Od siódmej ... aż do jednej,

Od jednej do żadnej!

Od tego mi pomagaj najpierw Bóg

Ojciec,

Po wtóre Bóg syn, po trzecie Duch

Św.

In his discussion of the oldest documented "poetry, spells, and evil charms," Czernik quotes two variants of a text illustrating how a spell may be transformed into a prayer [1962: 240]. The first is a magical text containing the motif of the pagan cult of the goddess of the dawn, to whom young girls addressed their spell-prayer for a husband. The original variant reads:

Zorze, zorzeczeńki!

Wszystkieśta moje siostruczeńki!

Siadajta na konia wronego

I jedźta po towarzysza mojego.

Żeby on nie mógł beze mnie ni spać,

Ni jeść, ni siadać, ni gadać.

Żeby ja mu się spodobała we stanie (stojąc),

W robocie, w ochocie.

The new formulation which takes its place drops the motif of the Morning Star and the Evening Star (zorze) substituting them with ecclesiastical motifs, such that the spell takes on the form of a prayer:

Żeby ja była wdzięczna i przyjemna

Bogu i ludziom, i temu

Towarzyszkowi swojemu,

Nie moją myśla, nie moją mowa, nie moją mocą

Ino Pana Jezusa i Najświętszej

Panny dopomoca

Abyż mi ta Najświętsza dopomogła, pobłogosławiła

I dobrymi ludźmi opatrzyła.
Oh Morning Star and Evening Star!

You are my sisters!

Please mount a black horse

And ride off to bring my comrade.

So that without me he can neither

sleep,

Nor eat, nor sit, nor talk.

So that I look attractive to him when

standing

May I be grateful and pleasing

To God and people, and to

My companion

Not by my thought, not by my

words, not by my power

Only with the assistance of Jesus

Christ and the Most Holy Virgin

May the Most Holy Lady help me

and bless me

And put me in the company of good people.
At work and am desired. 
Belief in the power of a heavenly deity to intervene, something appearing not just in aphrodisiac magic, was supplanted by Christian deities, especially by the Virgin Mary, who becomes Mary, the Morning Star, apostrophized in a distinctly Christian way as Stella matutina, a term taken from the popular Litany of Loretto [Forstner 1990: 104]. This belief was also subordinated to the Christian God, for example, the Morning Star and the Evening Star come to be described as Christ's servants. This symbolic parallelism also supports the idea that prayer structures and magical structures are in essence identical [see further Brzozowska-Krajka 1998: 92, passim]. We may obtain a more complete view of this identity in the structural pattern of morning and evening prayers, which were usually made up of exactly the same ingredients as the complex magic acts in magic medicine; in Polish folklore an introductory prayer was said in the first, preparatory stage of complex magic acts. This would be a canonical prayer, the Lord's Prayer, the Hail Mary or the Creed (Wierze w Boga), which would then be followed by a magic formula. It is precisely in the case of morning and evening prayers, in which the magic formula was replaced by a certain private (individual) prayer depending on the time of day, that we may observe a similar pattern. In folk material collected in the Rzeszów region we find the comment that the family intoned this private prayer along with saying a canonical morning prayer (the reason for intoning the prayer was to ensure that a blessing followed) [Kotula 1976: 318]. Thus the time and the method of recital suggest that what we have here is a case of magical incantation with its special power already transposed to the language of religion with the aim of obtaining God's grace [Kowalewski 1920: 31]. This identity may be also perceived very clearly in objects used for enchantment, for example in aphrodisiac magic (the so-called carowidetka). These objects included "church items" - tassels from banners, stoles, altar towels or pieces of church candle [Kolberg 1963: 207]. Magic and religion thus served a common cause - the practical goal of conjuring happiness. The dominant theme of the coexistence among the peasants of two religious models, albeit unremarked by them, is most clearly revealed in the preventive and protective functions of verbal texts and the magical and magical-religious actions that accompanied them. It is also to be seen, as already noted, in white magic, that is in positive, constructive ritual actions which are designed to bring good fortune, such as in the complex magic acts of folk medicine, aphrodisiacs, and so on. 
Examples of so-called black magic, very rare in Polish ethnographic and folklore sources, transfer this coexistence to the area of negative, destructive rituals, such as that of "singing to death," something known mainly in recordings from Mazuria in northern Poland. According to Biegeleisen, this type of maleficium is an Indo-European method of enchantment, well-known among the Germans and the Romance peoples [1929: 56]. It was believed that "if someone is so angry at someone else as to wish him or her dead, he/she can achieve this by singing a religious song in the morning and in the evening, and the target of the hatred will then surely die." This general conception had its own performance scenario with precise directions:

Sing a whole psalm (evidently Psalm 94) three times backwards for a whole year ... at 6 am and $6 \mathrm{pm}$ in the same place and in the same posture, each time adding the Lord's Prayer, said twice without the "Amen," and the third time with the "Amen." As soon as the person at prayer deviates from the exact hour or changes his location or posture, or makes a mistake during the prayer, he will be struck by the death ... he had wished upon another. Death shall come on the last day the prayer is said, after a year has lapsed.... In Wielbark these prayers are usually said in a cellar, and singing to death is also wellknown and very widespread in Szczytno. [Toeppen 1892: 397]

Negative rituals are the most powerful attestation of the pragmatic understanding of religion, but also reveal conflict of an axiological nature, since the protection of life was at the summit of both the folk hierarchy of values and religious ideology, which viewed life as a gift from God.

In making generalizations it should be stated that a certain type of magicalized religiosity is characteristic of Polish folk piety in its traditional dimension and that it illustrates the co-existence of the two religious models discussed. This may be metaphorically and literally defined by the maxim, "a candle for the Lord God, and a stub for the Devil," or its variant, "serve God and do not anger the Devil" [Krzyżanowski 1994: 82-84]. In the Adagia Polonica of 1632 the Jesuit chronicler Grzegorz Cnapius defined this proverb as a "dictum plebeium," a peasant saying, noting at the same time that Christians should not use it in its literal sense, but should understand it allegorically (sensu allegorico) [quoted in Krzyżanowski 1994: 82]. Polish ethnographic and folklore sources from the nineteenth and early twentieth centuries, however, suggest that the first tendency (understanding literally) is dominant and that the folk devil is not always the Christian hypostasis of evil in them. In these sources the folk devil is still a figure from folk demonology, that is, lower mythology). He is an ambivalent character, able both to cause damage and bring benefits (for 
example, by making a deal with man). Hence communication between man and mythological characters was such an important part of folk knowledge. This is why the proverbs mentioned above ("a candle for the Lord God, and a stub for the Devil," or "serve God but anger not the Devil") illustrate the essence of the problem of dual belief. It defines the relationship between Christian mythology and folk mythology as loyalty to two "gods," thereby testifying to the co-existence of these two kinds of outlook in Polish folklore.

Trans. by R. A. Orr

\section{NOTES}

1 Compare, for example, the following prayer-books: Zbiór wybornego i gruntownego nabożeństwa na codzienne, tygodniowe, miesięczne, w czasy przygodne, $\mathrm{w}$ dni świẹte, roczne i około świętych sakramentów podzielonego (Catalogue of Splendid and Serious Worship Assigned to Daily, Weekly, Monthly, and Annual Holy Days, as well as for Occasions and around the Holy Sacraments), $3^{\text {rd }}$ edition, Warsaw: Druk XX Missyonarzy, 1807; Złoty ołtarzyk wonnego kadzenia przed Stolica Boża to jest modlitwy rozmaite, które duch goracy na wonność Panu Bogu słodkości chwały jego ofiarować może. Z przydatkiem niektórych nabożnych pieśni (The Golden Altar of Fragrant Adoration before the Throne of God, i.e., Varied Prayers, which a Fervent Spirit May Offer up to the Sweet Glory of the Lord God. With the Addition of Some Hymns), place of publication and publisher unknown, 1821; and many other nineteenth- and twentieth-century prayer books.

\section{WORKS CITED}

Biegeleisen, H. 1929. Lecznictwo ludu polskiego [Polish Folk Medicine], Cracow: Polska Akademia Umiejętności.

Brzozowska-Krajka, A. 1998. „The Magic of a Good Beginning - the Mediating Structure of Daybreak." In A. Brzozowska-Krajka, Polish Traditional Folklore: The Magic of Time, Boulder: East European Monographs; Lublin: Maria Curie-Skłodowska University; New York: Columbia University Press, 73-114. 2004. "'Chroń i prowadź do nieba....' Mediacyjna struktura aniołów w folklorze polskim" [Protect and lead to Heaven ... The mediatory framework of angels in Polish folklore]. In J. Ługowska, J. Skawiński (eds), Anioł w literaturze i kulturze polskiej [The Angel in Polish Literature and Culture]. Wrocław: Oficyna Wydawnicza „Atut," 419-26.

Czernik, S. 1962. „Poezja zaklęć i uroków” [The poetry of incantations and charms]. In S. Czernik, Stare złoto. O polskiej pieśni ludowej [Old Gold: On Polish Folksong]. Warsaw: Państwowy Instytut Wydawniczy, 237-46.

1971. „Polska poezja magiczna” [Polish Magical Poetry]. In S. Czernik (comp.), Sny i widma [Dreams and Phantoms]. Warsaw: Ludowa Spółdzielnia Wydawnicza, 47-80. 
Eliade, M. 1997. W poszukiwaniu historii i znaczenia religii [In Search of the History and Symbolism of Religion], trans. A. Grzybek. Warsaw: Wydawnictwo KR.

Freedberg, D. 1989. Power of Images. Studies in the History and Theory of Response. Chicago: University of Chicago.

Forstner, D. 1990. Świat symboliki chrześcijańskiej [The World of Christian Symbolism], tr. W. Zakrzewska et al. Warsaw: Instytut Wydawniczy PAX.

Gimbutas, M. 1987. "Slavic Religion." In M. Eliade (ed.), The Encyclopedia of Religion. Vol. 13. New York: MacMillan, 353-61.

Guriewicz (Gurevich), A. 1987. Problemy średniowiecznej kultury ludowej [Issues of Medieval Folk Culture], trans. Z. Dobrzyniecki. Warsaw: Państwowy Instytut Wydawniczy.

Hernas, C. 1976. „Wstęp” [Introduction]. In F. Kotula. Znaki przeszłości. Odchodzace ślady zatrzymać w pamięci [Signs of the Past. Keeping Alive the Memory of Receding Traces]. Warsaw: Ludowa Spółdzielnia Wydawnicza, 5-22.

Karwot, E. 1955. Katalog magii Rudolfa. Źródło etnograficzne z XIII w. [Rudolf’s Magic Catalogue: An Ethnographic Source from the XIII Century]. Wstęp [Introduction] J. Gajek. Wrocław: Ossolineum.

Kibort, J. 1897. „Wierzenia ludowe w okolicach Krzywicz w pow. wilejskim” [Folk Beliefs around Krzywicze in Vilno District], Wisła, 11: 321-36.

Kolberg. O. 1963. Dzieła wszystkie [Collected Works]. Vol. 19. Kieleckie. Part 2. Wrocław - Poznań: Państwowe Wydawnictwo Muzyczne - Ludowa Spółdzielnia Wydawnicza.

Kotula,. F. 1976. Znaki przeszłości. Odchodzace ślady zatrzymać w pamięci [Signs of the Past. Keeping Alive the Memory of Receding Traces]. Warsaw: Ludowa Spółdzielnia Wydawnicza.

Kowalewski, Father T. 1920. Liturgika czyli wykład obrzędów kościoła katolickiego podług dzieła ks. Innocentego Frenkla [Liturgy, that is, the Presentation of Catholic Rites According to the Work of Father Innocenty Frenkel]. Płock: Druk Braci Detrychów.

Krzyżanowski, J. 1994. Mądrej głowie dość dwie słowie. Pięć centuryj przysłów polskich i diabelski tuzin z hakiem [Two Words are Enough for the Wise. Five Centuries of Polish Proverbs and the Devil's Dozen and More]. Vol. 1. Warsaw: Państwowy Instytut Wydawniczy.

Levin, E. 1991. "Dvoeverie and popular religion." In S. K. Batalden (ed.), Seeking God: The Recovery of Religious Identity in Orthodox Russia, Ukraine and Georgia. De Kalb: Northern Illinois University Press, 31-52.

Novikova, M. O. 1993. "Khristianski elementi v zamovlianniakh" [Christian elements in healing charms]. In M. N. Moskalenko (comp.), M. O. Novikova (intro. and commentary), Ukrainski zamovliannia [Ukrainian Healing Charms]. Kyiv: Vydavnytstvo Khudozhnoi Literatury "Dnipro," 291-300.

Siarkowski, W. 1880. "Materiały do etnografii ludu polskiego z okolic Kielc" [Sources for Polish folk ethnography from the Kielce area]. Part 3. Zbiór Wiadomości do Antropologii Krajowej, 4: 83-185.

Toeppen, M. 1892. „Wierzenia mazurskie” [Beliefs in Masuria], trans. from German by E. Piltzówna. Wisła, 6: 391-420.

Tokarska-Bakir, J. 2000. Obraz osobliwy. Wielkie opowieści. Hermeneutyczna lektura źródeł etnograficznych [Distinctive Image. Great Stories. A Hermeneutic Reading of Ethnographic Sources]. Kraków: Universitas. 
Tolstaia, S. M. 1995. "Sakralnoe i magicheskoe v narodnom kulte sviatykh" [The sacred and the magical in the folk cult of the saints]. In J. Bartmiński, M. JasińskaWojtkowska (eds.), Folklor. Sacrum. Religia [Folklore. The Sacred. Religion]. Lublin: Instytut Europy Środkowo-Wschodniej, 38-46.

2001. "Magiczne funkcje negacji w tekstach sakralnych" [Magical functions of negation in sacral texts], trans. R. Lewicki. Etnolingwistyka, 13: 117-25.

Witowt, J. 1905. „Przyczynki do zamawian” [Contributions to casting spells] Wisła, 19: 556-63.

"Zbiór generalny wszystkich grzechów z przykazań Boskich...." [General Catalogue of All Sins from the Divine Commandments....], z rękopisu podał J. Stecki [copied from the manuscript by J. Stecki]. 1901. Wisła, 15: 653-55.

Zernov, N. 1967. Wschodnie chrześcijaństwo [Eastern Christianity], trans. J. S. Łoś. Warsaw: Instytut Wydawniczy PAX. 